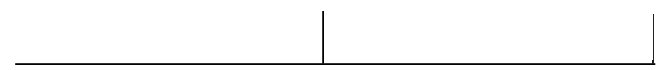

Rev. Latinoam. Psicopat. Fund., São Paulo, v. 14, n. 3, p. 563-565, setembro 2011

Feios, sujos e malvados sob medida: a utopia médica do biodeterminismo, São Paulo (1920-1945)

Luis Ferla

São Paulo: Alameda, 2009

\title{
Feios, sujos e malvados sob medida: a utopia médica do biodeterminismo, São Paulo (1920-1945)
}

Flavio Edler

Os pesquisadores que hoje estudam as causas do comportamento criminoso ou violento e antissocial, mobilizando marcadores biológicos - genes, hormônios e imagens cerebrais - como elementos componentes da personalidade individual que devem ser traduzidos em riscos sociais, recompõem o fio de uma longa história.

Feios, sujos e malvados sob medida é um trabalho primoroso, que nos relata um momento crucial em que esta utopia médica biodeterminista almejou patologizar o comportamento socialmente desajustado, desviante ou, mais precisamente, delinquente, em terras bandeirantes, no período que se estende da crise do modelo oligárquico de ordenação política até o fim da Era Vargas. A análise minuciosa do universo de produção, reprodução e circulação do discurso em criminologia positivista, herdeira da escola antopométrica lombrosiana, dentre outras mais sofisticadas e contemporâneas - a biotipologia constitucional, a psicanálise, a psicologia comportamental e endocrinologia - revela a abrangência dos espaços institucionais onde ideias e conceitos mesclavam-se a práticas humanas concretas. Nas cátedras universitárias de Medicina Legal das escolas médicas ou 
jurídicas, na Sociedade de Medicina Legal e Criminologia de São Paulo, na Escola de Polícia, no Instituto de Criminologia, nos três Congressos de Medicina Legal, nos dois laboratórios de antropologia criminal, da polícia e da penitenciária de São Paulo e nas cinco revistas especializadas as disfunções e desequilíbrios do corpo eram acionados para explicar as disfunções e desequilíbrios da sociedade. Entretanto, o prestígio intelectual da medicina que se voltou ao escrutínio do corpo social, orientando seu arsenal diagnóstico, terapêutico e profilático para os problemas sociais cotidianos, e elegeu os delinquentes, os trabalhadores e os homossexuais como populações-alvo de sua investigação, encontrou a oposição de outros atores, dentro e fora da profissão. Não só delegados de polícia, juristas e magistrados desconfiavam ou interpelavam abertamente os pressupostos do discurso biodeterminista, como outros saberes psiquiátricos, psicológicos e sociológicos forçavam sua constante transformação, adaptação e acomodação. Efetivamente, como sugere a leitura, as aporias do Livre-arbítrio ou do Determinismo pertencem à história sequencial escrita pelos seguidores do Direito Penal Positivo. Como demonstra Luis Ferla, a multidisciplinaridade se impôs ao relativizar o determinismo radical e ampliar a influência do ambiente social, por meio do conceito de periculosidade.

O terceiro capítulo, de inspiração latouriana, dedicado ao estudo do exame médico-legal e à ampla circulação que teve no meio jurídico-administrativo, revela as estratégias em transformá-lo em prerrogativa exclusiva do médico-legista. A análise sistêmica das taxas hormonais, da educação defeituosa, das taras e estigmas herdados, do alcoolismo, da morfologia anômala; tudo isso tornava a produção do laudo pericial em jurisdição exclusiva da Medicina Legal. Aqui se expõe, com rigor analítico e argumentativo convincente, as tendências endógenas ao campo, que conduziram, por um lado, a algumas vitórias do discurso competente, com a criação do Manicômio Judiciário, o livramento condicional, e a medida de segurança - aprovada no novo Código Penal de 1940 - e, por outro, à sua inviabilidade administrativa, pelo seu custo altíssimo que crescia juntamente com a população carcerária.

Outro mérito a destacar no livro, refere-se ao método pelo qual seu autor articulou o discurso biodeterminista ao contexto. A principal renovação metodológica nos estudos das ideias científicas tem sido a ênfase em entendê-las não como pertencendo a um espaço etéreo, mas impregnadas pelos contextos em que foram enunciadas, e se relacionando intimamente com os alinhamentos políticos, teóricos e ideológicos dos indivíduos que as articularam. Assim, menos atenção tem sido dada às filiações a determinada tradição científica ou escola de pensamento, do que ao contexto social em que as ideias são acionadas por determinados atores ocupando espaços institucionais, com específica formação teórica e posição social. 
Supérflua, nessa perspectiva da história social das ideias filosóficas e científicas, é a tentativa de inscrever as obras dos autores nacionais, como "cópias" de "modelos" europeus. Esta hierarquização taxonômica é herdeira da lógica dualista que antepõe um centro (Europa), superior, puro, a uma periferia (Brasil), abastardado, impróprio, alienado. Seguindo este esquema, muitos historiadores concentraram seus esforços analíticos na identificação das "distorções" produzidas pela transposição das ideias científicas e filosóficas européias para uma região supostamente incompatível com a cultura de onde provinham. No entanto, nem os modelos teóricos originários são perfeitamente consistentes e seus significados transparentes, nem sua aplicação ao contexto nacional é sintoma de um pathos sociológico escondido. Estas abordagens necessariamente simplificam a história das ideias europeias, aplainando seus intrincados percursos.

Resumidamente, é simplista e ilusório falar de pensamento médico ou jurídico europeu, como se tratasse de uma entidade fixa e homogênea, como demonstra o trabalho de Pierre Darmon. Da mesma forma, os discursos médicos aqui produzidos não seriam jamais distorções de um modelo preexistente, já que o significado de um enunciado depende das suas condições de inteligibilidade, isto é, do contexto em que foi proferido, da forma como circulou e dos diferentes públicos que o assimilaram. Assim, como revela Luis Ferla, tal processo de apropriação foi necessariamente contraditório devido à presença, no interior de sociedade letrada republicana, de uma pluralidade de agentes e discursos, cujos códigos conduziam a diferentes modos de apropriação,

Essa sensibilidade historicista - que se traduz no exercício de um contextualismo linguístico, isto é, no estudo das ideias em contexto - é um dos principais méritos deste livro sobre a utopia médica do biodeterminismo pregada pela Escola Positiva no Brasil, durante a primeira metade do século XX. Como nele se argumenta de modo persuasivo, sua introdução no ambiente médico e jurídico paulista, principalmente ligado ao aparelho repressor, foi obra de um grupo de profissionais, ligados à Medicina Legal. Longe de se tratar de uma história linear e bem-sucedida, a tentativa de interpretar os comportamentos considerados socialmente desviantes como uma perturbação patológica logrou, ainda assim, razoável grau de institucionalização.

\section{Flavio EdLer}

Historiador; professor do Programa de Pós-Graduação em História das Ciências e da Saúde da Casa Oswaldo Cruz/Fundação Oswaldo Cruz - COC/Fiocruz (Rio de Janeiro, RJ, Br). Fundação Oswaldo Cruz, Casa Oswaldo Cruz, Departamento de Pesquisa Av. Brasil, 4036 - Manguinhos 21040-361 Rio de Janeiro, RJ, Brasil e-mail: edler@fiocruz.br 